\title{
Article \\ Selective Extraction of Bioactive Phenylethanoids from Digitalis obscura
}

\author{
José Francisco Quílez del Moral ${ }^{1}$ **(D), Álvaro Pérez ${ }^{1}$, María José Segura Navarro ${ }^{1}$, Alberto Galisteo ${ }^{1}$, \\ Azucena Gonzalez-Coloma ${ }^{2}$ D, María Fe Andrés ${ }^{2}$ (D) and Alejandro F. Barrero ${ }^{1, *}$ \\ 1 Department of Organic Chemistry, Institute of Biotechnology, University of Granada, 18071 Granada, Spain; \\ alvaroapr@ugr.es (Á.P.); mariajoseseguranavarro@gmail.com (M.J.S.N.); albertogapre@ugr.es (A.G.) \\ 2 Institute of Agricultural Sciences, CSIC, 28006 Madrid, Spain; azu@ica.csic.es (A.G.-C.); \\ mafay@ica.csic.es (M.F.A.) \\ * Correspondence: jfquilez@ugr.es (J.F.Q.d.M.); afbarre@ugr.es (A.F.B.); Tel.: +34-958-243-185 (A.F.B.)
}

Citation: Quílez del Moral, J.F.; Pérez, Á.; Navarro, M.J.S.;

Galisteo, A.; Gonzalez-Coloma, A.; Andrés, M.F.; Barrero, A.F. Selective Extraction of Bioactive Phenylethanoids from Digitalis obscura. Plants 2021, 10, 959. https:// doi.org/10.3390/plants10050959

Academic Editor: Andrea Ghirardo

Received: 12 April 2021

Accepted: 6 May 2021

Published: 12 May 2021

Publisher's Note: MDPI stays neutral with regard to jurisdictional claims in published maps and institutional affiliations.

Copyright: (c) 2021 by the authors. Licensee MDPI, Basel, Switzerland. This article is an open access article distributed under the terms and conditions of the Creative Commons Attribution (CC BY) license (https:/ / creativecommons.org/licenses/by/ $4.0 /)$.

\begin{abstract}
Cardenolide-free extracts from Digitalis obscura showed significant antifeedant effects against the aphid Myzus persicae and this activity correlated with their phenylethanoid content. The content in phenylethanoids of Digitalis obscura has been studied. Maceration of the aerial parts of D. obscura was used for the selective extraction of the natural compound rengyolone (1) and the aglycone of cornoside (compound 3). Pure rengyolone (1) can be obtained from D. obscura in approximately $90 \%$ purity from fresh plant from the $\mathrm{CHCl}_{3}$ soluble fraction of the ethanolic extract ( $0.8 \%$ yield). The ethanol extraction of freshly collected D. obscura showed the presence of compound $\mathbf{3}$ as the only phenylethanoid. Compound $\mathbf{3}$ was proven to easily evolve to rengyolone. Due to this instability, and although its presence in plants has been previously reported, the spectroscopical data of $\mathbf{3}$ are reported herein for the first time. Selective mono-acetylation of compound of 3 led to the active natural compound hallerone (5). The aphid antifeedant (against Myzus persicae) and nematicidal (against root-knot nematode Meloidogyne javanica) activities of these compounds have been evaluated. Here we report for the first time on the aphid antifeedant effects of 1, 3, and 5 . Additionally, the nematicidal activity of hallerone (5) is described here for the first time.
\end{abstract}

Keywords: selective extraction; natural products; pesticides; antifeedant; nematicidal

\section{Introduction}

Food safety and environmental concerns related to the use of pesticides have resulted in more restricted regulatory frameworks worldwide, reducing the number of commercial products available for crop protection. Therefore, new, safer, and effective protection agents are needed. Natural products have been known for decades as crop protection agents [1-4]. Many active ingredients of botanical pesticides, such as azadirachtin or essential oils, come from medicinal plants [5].

During the last decade, our research groups have contributed to the discovery of new natural or natural-derived biopesticides from medicinal plants [6], and some of these compounds have been patented based on their activity [7].

Among traditional medicinal plants, the genus Digitalis contains species used for the treatment of congestive heart failure [8]. Cardenolides are the pharmacologically active components of Digitalis [9] and well-known plant defenses sequestered by specialist insects that deter feeding in nonadapted insects [10] and have nematicidal effects [11] depending on their molecular structure. In addition to toxic cardenolides, Digitalideae contain phenylethanoids, such as rengyolone (1) and cornoside (2), which are considered chemotaxonomic markers [12]. Rengyolone (or halleridone) (1) has a wide array of pharmacological activities, including cytotoxicic [13-15], anti-inflammatory [16], antiplasmodial [17], and antioxidant [18] while cornoside (2) has reported cytotoxic effects [19]. However, little is known on the plant defensive properties of these compounds. 
Digitalis obscura is an endemic medicinal plant growing in the Iberian Peninsula and Northern Morocco. In the province of Granada (Andalusia, Spain), this species has been used in ethnoveterinary practices, specifically for traumatic lesions and poisoning [20]. D. obscura contains toxic cardenolides [21,22], and its cultivation in vitro has been extensively studied [23]. However, little is known about its content in additional metabolites involved in plant defense with lower toxicity to vertebrates.

In this study, we have explored the presence of phenylethanoids in D. obscura to search for new plant defense-based biopesticide models. Cardenolide-free D. obscura extracts have been prepared, phenylethanoids have been selectively extracted and the plant protection properties (insect antifeedant effects against Spodoptera littoralis, Myzus persicae and Rhoplaosiphum padi, and nematicidal action against Meloidogyne javanica) of these extracts and products tested.

\section{Results and Discussion}

\subsection{Digitalis Obscura Cardenolide-Free Extracts and Their Biological Effects}

The selective extraction of natural products from their sources represents a determining step in terms of efficiency and viability $[24,25]$. All this makes the search of protocols for the selective extraction of natural products a demanding task. Here we have developed a selective extraction method to obtain cardenolide-free D. obscura extracts and the natural compound regyolone (1).

Aerial parts of Digitalis obscura collected in July 2020 were used to obtain plant extracts by maceration using solvents of different polarity such as tert-butylmethyl ether (MTBE), ethyl acetate $(\mathrm{EtOAc})$ or ethanol $(\mathrm{EtOH})$. Additionally, extracts were also obtained from the powdered aerial parts with $70 \% \mathrm{EtOH}$ using a Soxhlet extractor (reflux). The extracts content was qualitatively analyzed by NMR (Table 1).

Table 1. Qualitative content in different extracts of D. obscura ${ }^{\text {a }}$.

\begin{tabular}{|c|c|c|c|c|c|c|}
\hline Entry & Method & Fats & Phenyletanoids & Phenyletanoids (Glycosylated) & Cardenolides & Free Sugars \\
\hline 1 & $\begin{array}{l}70 \% \mathrm{EtOH} \\
\text { (reflux) }^{\mathrm{b}}\end{array}$ & $\operatorname{tr}^{\mathrm{e}}$ & + & ++ & + & ++ \\
\hline 2 & EtOH (reflux) & $\operatorname{tr}$ & + & ++ & + & ++ \\
\hline 3 & $\operatorname{MTBE}\left(\mathrm{rt}^{\mathrm{c}}\right)$ & ++ & + & - & - & - \\
\hline 4 & EtOAc (rt) & ++ & + & - & - & - \\
\hline 5 & $\mathrm{EtOH}\left(40^{\circ} \mathrm{C}\right)$ & $\operatorname{tr}$ & ++ & - & - & + \\
\hline 6 & $\mathrm{EtOH}\left(40^{\circ} \mathrm{C}\right)^{\mathrm{d}}$ & $\operatorname{tr}$ & ++ & - & - & + \\
\hline
\end{tabular}

a Dried during 15 days. ${ }^{b}$ Powdered aerial parts. ${ }^{c}$ Room temperature. ${ }^{d}$ Fresh plants (extracted the day after the collection). ${ }^{e}$ Traces).

The conventional EtOH: $\mathrm{H}_{2} \mathrm{O}$ extraction of the powdered aerial parts of the plant yielded glycosylated phenylethanoids and free sugars as major compounds, along with minor proportions of cardenolides (entry 1, Table 1). Similar results were found when the fresh aerial parts were extracted again with refluxing $\mathrm{EtOH}(100 \%)$, although a moderate increase in the ratio of phenylethanoids was noticed (entry 2, Table 1).

With the aim of achieving a selective extraction of non-glycosylated phenylethanoids, extractions of the aerial parts using less polar solvents and/or lower temperatures were tested (entries 3-6, Table 1). In entries 3-4, although the presence of non-glycosylated phenylethanoids was observed, fats were the major compounds in the extract. The use of $\mathrm{EtOH}$ at $40^{\circ} \mathrm{C}$ (entry 5, Table 1) led to the selective extraction of phenylethanoids.

The crude extracts containing phenylethanoids (entry 3-MTBE and entry 6-ethanolic, Table 1) were tested against insect pests (Spodoptera littoralis, Myzus persicae and Rhopalosiphum padi) and phytoparasitic nematodes (Meloidogyne javanica) of great economic importance. Thus, the moth S. littoralis, also known as Egyptian cotton leafworm, was reported to be a pest of this plant and of a wide variety of vegetable crops [26]. The aphid M. persicae is known to infect a large number of species from 40 plant families, with special prevalence in Brassica crops [27]. R. padi is also an aphid and is considered one of the most 
important cereal pests [28]. Root-knot nematodes (Meloidogyne sp.) are plant parasites of major agricultural importance [29]. Only M. persicae was significantly affected by these extracts ( 3 doses, 88-42 and 74-45\%SI) with EC 50 values of 40.1 (29.5-54.4, 95\% CL) and 27.9 $\left(10.58-49.5,95 \%\right.$ CL) $\mu \mathrm{g} / \mathrm{cm}^{2}$, respectively. Extract 3 (MTBE) contained more phenylethanoids than extract 5 (ethanolic) (Table 1), suggesting a correlation between the phenylethanoid content of the extract and the aphid antifeedant effect.

\subsection{Selective Extraction of Rengyolone (1)}

The extraction with EtOH at $40{ }^{\circ} \mathrm{C}$ (entry 5, Table 1) led to the selective extraction of phenylethanoids, which consisted in a mixture rengyolone (1) and compound 3 , the aglycone of the known phenylethanoid cornoside (2) (Figure 1a). Regarding these two compounds, it was noticed that upon standing for a few weeks in the freezer, diol 3 evolved completely to rengyolone (1) (Figure 1b).

Furthermore, the $\mathrm{CHCl}_{3}$ soluble fraction of the ethanolic extract (entry 5, Table 1) allowed for very efficient separation of rengyolone (1) from the sugar fraction. In fact, the ${ }^{1} \mathrm{HNMR}$ spectra of the $\mathrm{CHCl}_{3}$ soluble fraction of the ethanol extract (Figure 2a) and pure rengyolone (1) (Figure 2b) were almost identical.

When this $\mathrm{CHCl}_{3}$ soluble fraction was subjected to column chromatography, rengyolone was obtained along with a minor proportion of the saturated derivative of rengyolone, cleroindicin C (4) [30].

Rengyolone (or halleridone) (1) was first isolated from the medicinal plants Forsythia suspensa [31] and Halleria lucida [32]. Additionally, a compound with the same spectroscopic data of rengyolone/halleridone was isolated from Clerodendrum indicum and was named as cleroindicin F [30]. The synthesis of $\mathbf{1}$ using tyrosol as starting material has been described [33-35].

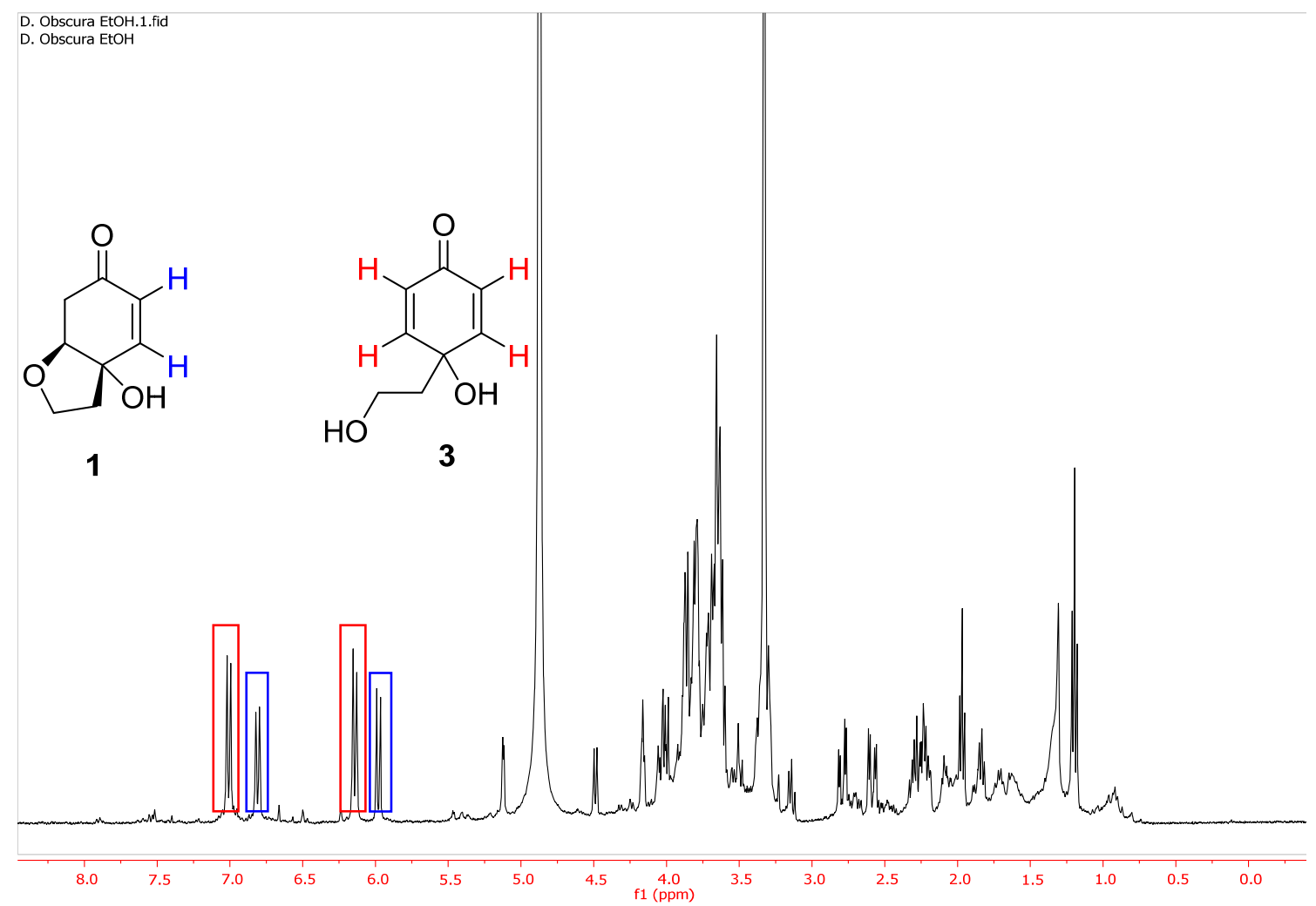

(a)

Figure 1. Cont. 


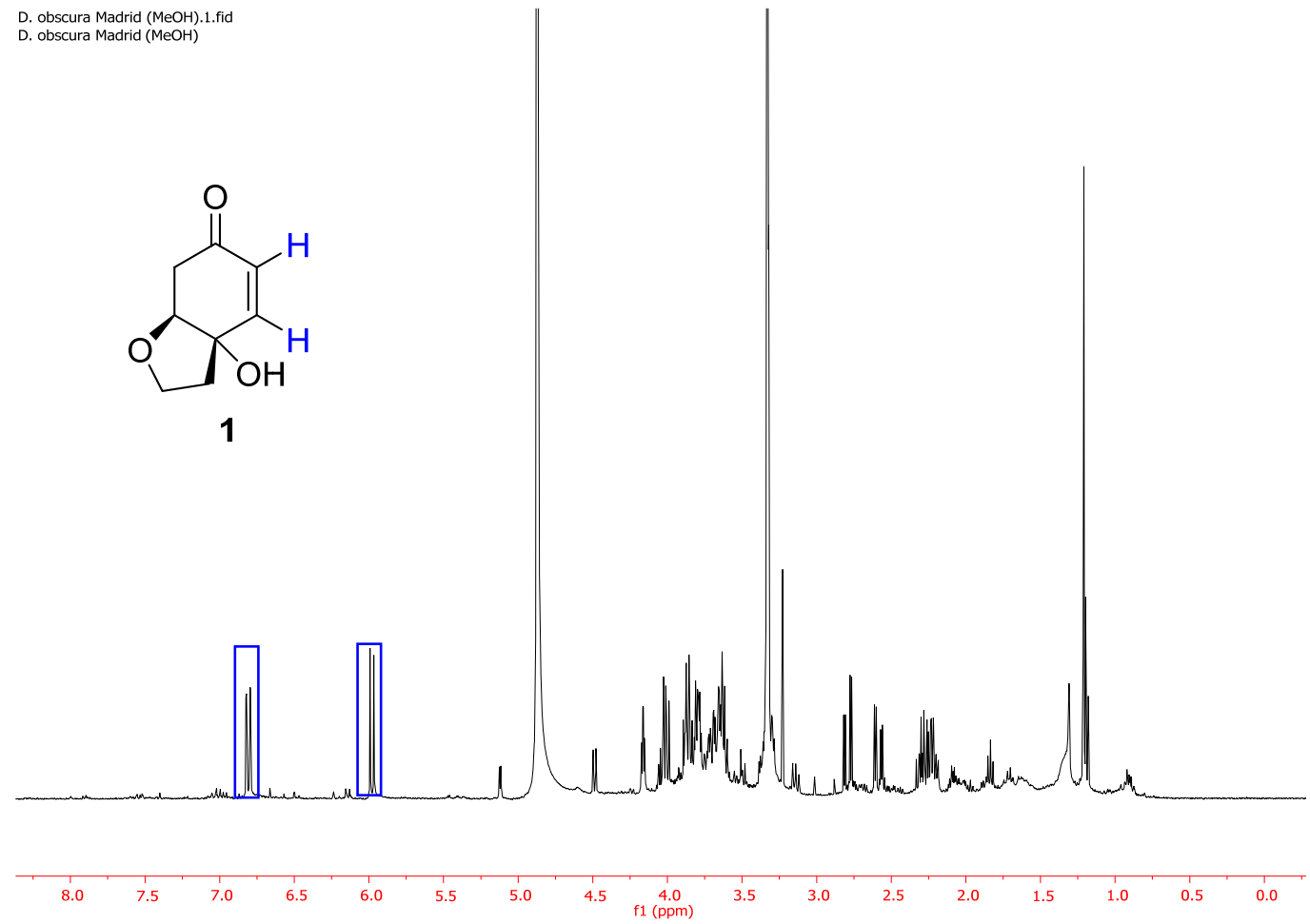

(b)

Figure 1. (a) ${ }^{1} \mathrm{H}$ NMR spectrum of the ethanolic extract of $D$. obscura just after the extraction (entry 5 , Table 1). (b) ${ }^{1} \mathrm{H}$ NMR spectrum of the same ethanolic extract of D. obscura a few weeks after the extraction.

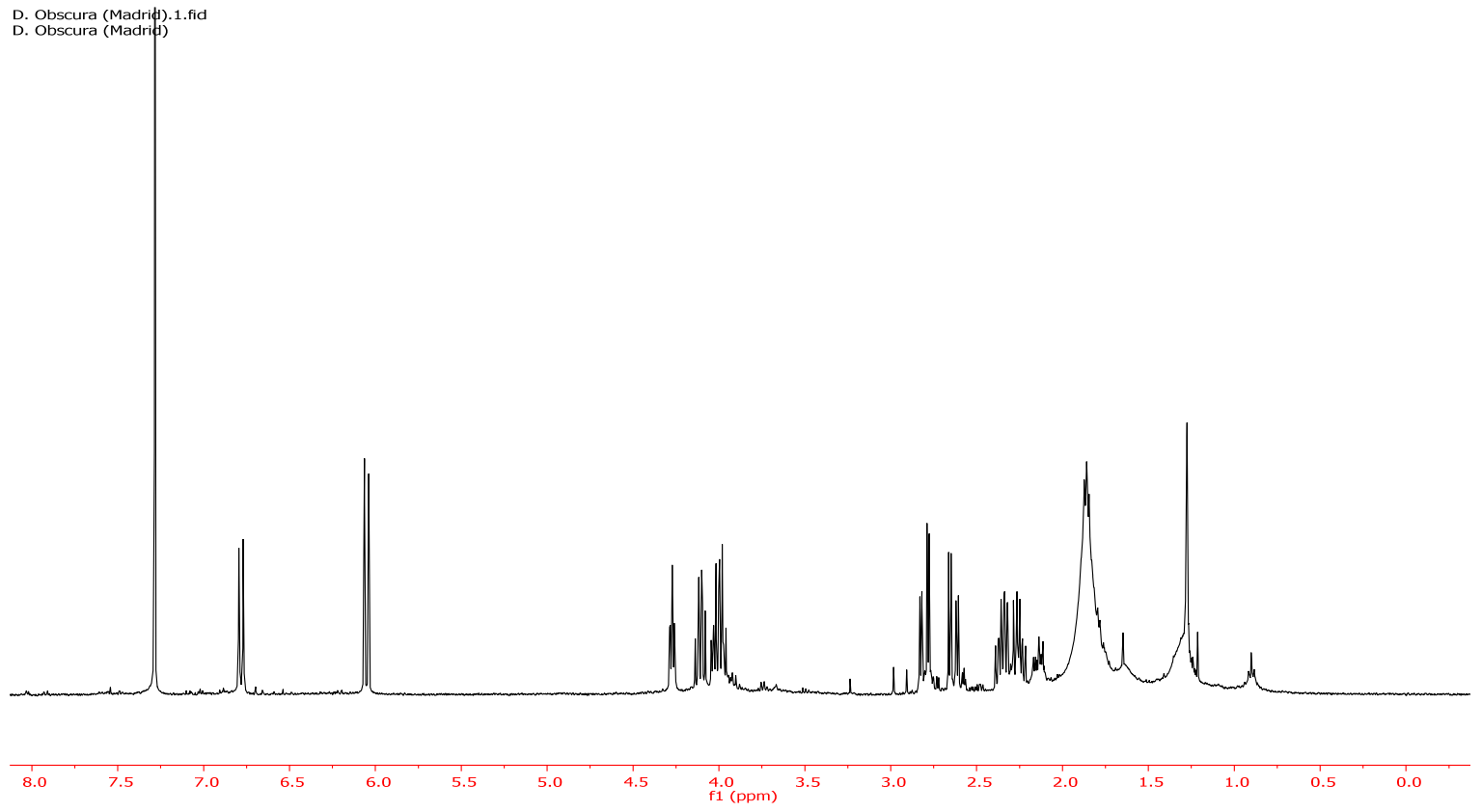

(a)

Figure 2. Cont. 


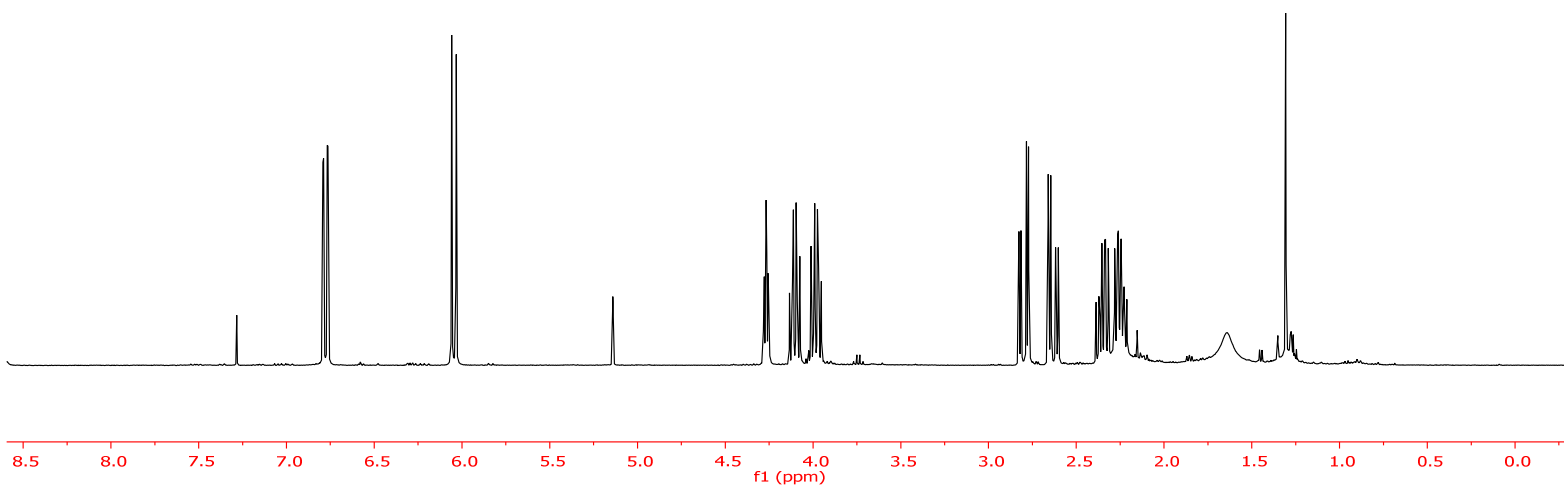

(b)

Figure 2. (a) ${ }^{1} \mathrm{H} \mathrm{NMR}$ of the $\mathrm{CDCl}_{3}$ soluble fraction of the ethanolic extract of D. obscura. (b) NMR of pure rengyolone.

In summary, pure rengyolone (1) can be obtained from D. obscura in approximately $90 \%$ yield purity from fresh plant using only two simple lab operations. Up to $640 \mathrm{mg}$ of rengyolone were obtained from $80 \mathrm{~g}$ of dry plant $(0.8 \%)$.

\subsection{Selective Extraction of Cornoside Aglycon (3)}

Compound 3 is the aglycon of the known compound cornoside (2), whose presence was also confirmed in the refluxing ethanol extract of D. obscura (entry 2, Table 1).

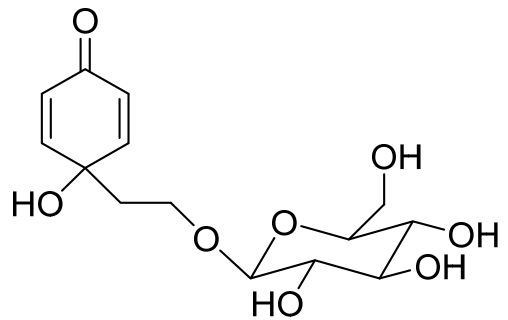

Cornoside (2)<smiles>O=C1CC[C@]2(O)CCO[C@H]2C1</smiles>

Cleroindicin C (4)

Cornoside (2) has been reported to be present in many species of Cornus [36] and Olea europea and Digitalis [12,37]. However, the occurrence of its aglycone, compound 3 has been always associated to rengyolone [12,38]. Possibly, due to this known instability of compound $3[37,39]$, no ${ }^{13} \mathrm{C}-\mathrm{NMR}$ data of this compound and of its biological activity could be found in the literature. All these led us to study the selective extraction and isolation of compound 3 in order to study both its possible activity as biopesticide and stability.

The known predisposition of the cornoside aglycon (3) to evolve towards rengyolone led us to perform the extraction of freshly collected D. obscura to avoid the possible Michael addition converting 3 into 1 due to the plant drying process. The analysis of the ethanol extract of fresh plant samples collected in March 2021 (entry 6, Table 1) showed the presence of compound 3 as the only phenylethanoid component (Figure 3). Only one column chromatography allowed to obtain pure 3 ( $0.4 \%$ from the fresh plant). 


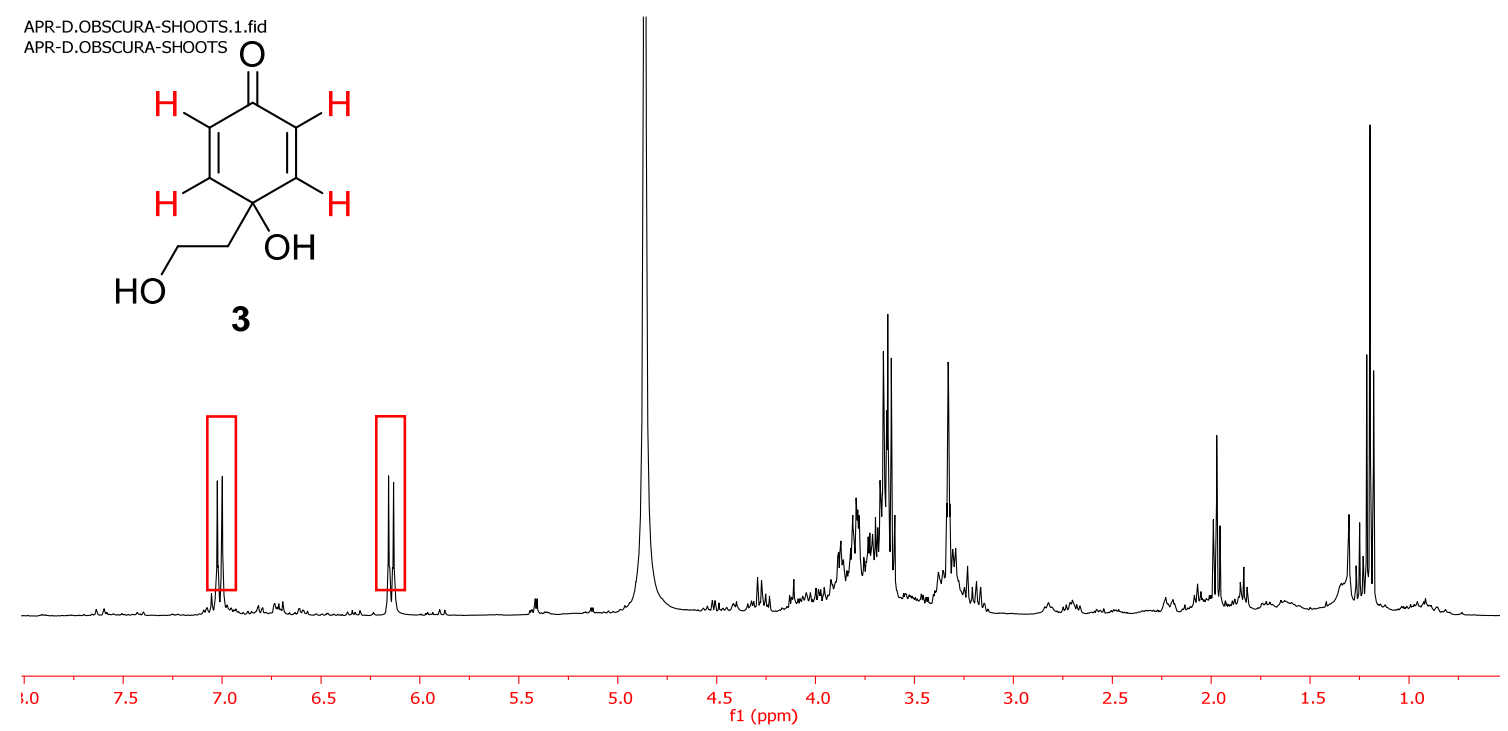

Figure 3. ${ }^{1} \mathrm{H}$ NMR spectrum of the ethanolic extract of D. obscura collected in March 2021.

With regard to the occurrence of compound 3, Jensen et al. [38] reported that the presence of this substance is probably due to the action of glycosidases on cornoside (2). To verify this hypothesis, we conducted an extraction of D. obscura collected in March 2021 with refluxing ethanol-a process that should deactivate the corresponding glycosidases, to find that compound 3 was still the more abundant phenylethanoid although the presence of cornoside (2) was also observed. This presence is easily rationalized as a result of the increase of the capacity of extraction of polar components when the temperature of the solvent is raised. This observation suggests that D. obscura actually produces compound 3 naturally in the early stages of its growth, and that, eventually, this compound is glycosylated to generate cornoside (2). In this regard, the occurrence of cleroindicin C (4) in D. obscura suggest that, at least to some extent, the cyclization of cleroindicin $C(4)$ to give rengyolone (1) could also take place in vivo.

Compound 3 was then acetylated. With this transformation, not only we could obtain the natural compound hallerone (5) [32], but also this could be a way of stabilizing compound 3 by precluding the intramolecular Michael addition leading to rengyolone (1). When the reaction was performed using acetic anhydride, mixtures containing the diacetylated compound (6) [40] were obtained. The acetylation of the tertiary alcohol was avoided by using acetyl chloride and collidine at $-78{ }^{\circ} \mathrm{C}$ [41], with hallerone (5) being obtained in a $65 \%$ yield.

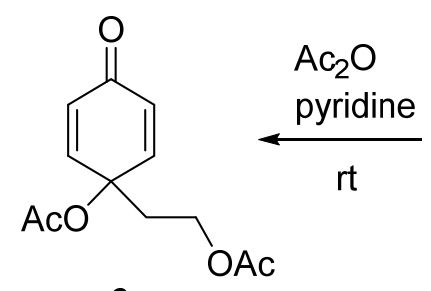

6<smiles>O=C1C=CC(O)(CCO)C=C1</smiles>

3

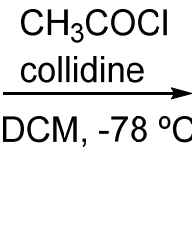

This compound was reported to possess antimicrobial and antifungal activity [42], showed moderate scavenging action on superoxide radicals, inhibited $\mathrm{H}_{2} \mathrm{O}_{2}$ induced reactive oxygen species production in HEK-293 cells [18], and its synthesis has been described by different authors [33-35].

\subsection{Bioactivity of Phenylethanoids}

Phenylethanoids 1, 3, 5, and 6 were tested against $M$. persicae and $M$. javanica (Tables 2 and 3$)$. At the maximum dose tested $\left(50 \mu \mathrm{g} / \mathrm{cm}^{2}\right)$, compounds 1 (4 doses, 
86-37 \%SI), 3 (3 doses, 76-28\%SI) and 5 (4 doses, 78-35\%SI) were effective. The activity of compound 5 , with an efficient dose $\left(\mathrm{EC}_{50}\right)$ of $12.5 \mu \mathrm{g} / \mathrm{cm}^{2}(7.0-22.095 \% \mathrm{CL})$ fell within the range of thymol ( $\mathrm{EC}_{50}$ of 7.6, 4.1-8.7 95\% CL) (Table 2), included as a positive control since this compound is an active ingredient of commercial biopesticides [5].

Table 2. Antifeedant effects of compounds 1, 3, 5 and 6 against Myzus persicae.

\begin{tabular}{ccc}
\hline Compound & \% SI $^{\mathbf{a}}$ & $\mathbf{E C}_{\mathbf{5 0}} \mathbf{b}^{\mathbf{b}\left(\boldsymbol{\mu g} / \mathbf{c m}^{\mathbf{2}}\right)}$ \\
\hline $\mathbf{1}$ & $86.31 \pm 5.74^{*}$ & $17.6(13.2-23.4)$ \\
$\mathbf{3}$ & $75.77 \pm 6.13^{*}$ & $25.9(18.5-36.1)$ \\
$\mathbf{5}$ & $76.81 \pm 5.51^{*}$ & $12.5(7.0-22.0)$ \\
$\mathbf{6}$ & $53.78 \pm 8.58$ & \\
Thymol & $81.8 \pm 7.7^{*}$ & $7.6(4.1-8.7)$ \\
\hline
\end{tabular}

a Percent setting (SI) inhibition at a dose of $100 \mu \mathrm{g} / \mathrm{cm}^{2}$. Values are means of twenty replicates. Values with asterisk $\left(^{*}\right)$ are significantly different according to Wilcoxon paired rank test $(p<0.05) .{ }^{\text {b }}$ Effective dose $\mathrm{EC}_{50}(95 \%$ lower-upper confidence limits) needed to produce $50 \%$ feeding/setting inhibition.

When these compounds were tested against $M$. javanica, hallerone 5 showed strong nematicidal effects (Table 3) with an $\mathrm{LD}_{50}$ of $0.034 \mathrm{mg} / \mathrm{mL}$ (Table 4 ), five times more effective than thymol, a reference compound with proven nematicidal activity $\left(\mathrm{LD}_{50}\right.$ value of $0.14 \mathrm{mg} / \mathrm{mL}$ ) [43].

Table 3. Nematicidal activity of compounds 1,3, 5, and 6 against $M$. javanica juveniles.

\begin{tabular}{cc}
\hline Compound & \% Mortality $^{\text {a }}$ \\
\hline $\mathbf{1}$ & $34.17 \pm 10.81$ \\
$\mathbf{3}$ & $2.47 \pm 1.56$ \\
$\mathbf{5}$ & $92.87 \pm 1.26$ \\
$\mathbf{6}$ & $20.34 \pm 2.52$
\end{tabular}

a Percent mortality at a dose of $0.5 \mathrm{mg} / \mathrm{mL}$. Values (\%) are means of four replicates (corrected according to Schneider-Orelli's formula [44].

Table 4. Comparative nematicidal effects of active compound 5 and thymol against $M$. javanica juveniles.

\begin{tabular}{|c|c|c|c|}
\hline Compound & $\begin{array}{c}\text { Dose } \\
(\mu \mathrm{g} / \mathrm{mg})\end{array}$ & $\begin{array}{c}\text { J2 Mortality } \\
(\%)^{a}\end{array}$ & $\mathrm{LD}_{50}{ }^{b}$ \\
\hline \multirow{5}{*}{5} & 1.0 & $92.87 \pm 1.23$ & \multirow[t]{5}{*}{$0.034(0.017-0.091)$} \\
\hline & 0.5 & $82.13 \pm 4.1$ & \\
\hline & 0.25 & $75.83 \pm 1.39$ & \\
\hline & 0.12 & $46.82 \pm 5.11$ & \\
\hline & 0.06 & $40.93 \pm 2.59$ & \\
\hline \multirow{5}{*}{ Thymol } & 1.0 & 100 & \multirow[t]{5}{*}{$0.14(0.131-0.143)$} \\
\hline & 0.50 & 100 & \\
\hline & 0.25 & $98 \pm 0.44$ & \\
\hline & 0.12 & $29.14 \pm 2.92$ & \\
\hline & 0.06 & $15.40 \pm 2.03$ & \\
\hline
\end{tabular}

a Percent mortality at a dose of $0.5 \mathrm{mg} / \mathrm{mL}$. Values (\%) are means of four replicates (corrected according to Schneider-Orelli's formula [44]. ${ }^{\mathrm{b}}$ Lethal dose in $\mathrm{mg} / \mathrm{mL}$ (upper-lower $95 \%$ confidence limits) calculated to give $50 \%\left(\mathrm{LD}_{50}\right)$ mortality by Probit Analysis.

This is the first report on the aphid antifeedant effects of $\mathbf{1}, \mathbf{3}$, and $\mathbf{5}$. The aglycon of $\mathbf{3}$, cornoside (2), had growth regulation effects on Rhodnius nasutus [45] and ethyljacaranone, structurally related to 5 , proved to be a potent antifeedant against S. littoralis and $M$. persicae while a jacaranone diol derivative only showed significant antifeedant effects on M. persicae, [46] supporting the aphid antifeedant effects of phelylethanoids. Additionally, the nematicidal activity of hallerone (5) is described here for the first time. It is interesting to note the structural specificity of this nematicidal effect. 


\section{Conclusions}

Cardenolide-free extracts from Digitalis obscura showed significant antifeedant effects against the aphid Myzus persicae, and this activity correlated with their phenylethanoid content.

Pure rengyolone (1) can be obtained from $D$. obscura in approximately $90 \%$ purity from fresh plant from the $\mathrm{CHCl}_{3}$ soluble fraction of the ethanolic extract ( $8 \%$ yield). The ethanol extraction of freshly collected D. obscura showed the presence of compound 3 as the only phenylethanoid.

This is the first report on the aphid antifeedant effects of 1,3 , and 5 . Additionally, the nematicidal activity of hallerone (5) is described here for the first time.

The efficient and selective extraction of these substances, which avoids laborious and costly separations, along with their antifeedant and selective nematicidal effects points out their potential as biopesticide models.

\section{Experimental Section}

\subsection{Plant Material}

Specimens of Digitalis obscura L. were collected in Prado Negro (37.0850844, -3.3798640 , Granada, Spain) in July 2020 and March 2021. Aerial plant parts (dried for 15 days or fresh) were obtained by maceration in different solvents (for more details and conditions, see Table 1). Extracts from powdered aerial parts were also obtained using a Soxhlet extractor for $12 \mathrm{~h}$ with a 7:3 mixture of EtOH: $\mathrm{H}_{2} \mathrm{O}$.

\subsection{Selective Extraction of Rengyolone}

Aerial parts of D. obscura ( $80 \mathrm{~g}$ ) collected in July 2020 were immersed in $\mathrm{EtOH}$ and heated at $40{ }^{\circ} \mathrm{C}$ for $2 \mathrm{~h}$. After evaporation of the solvent, $1.2 \mathrm{~g}$ of extract was obtained. The $\mathrm{CHCl}_{3}$ soluble fraction of this extract $(870 \mathrm{mg})$ was flash chromatographed (H:MTBE 2:1) to give $640 \mathrm{mg}$ of rengyolone (1) and $4 \mathrm{mg}$ of compound 4.

Rengyolone (1): ${ }^{1} \mathrm{H}$ NMR $\left(400 \mathrm{MHz}, \mathrm{CDCl}_{3}\right) \mathrm{d}=6.78(\mathrm{dd}, J=10.2,1.5 \mathrm{~Hz}, 1 \mathrm{H}), 6.05$ $(\mathrm{d}, J=10.2 \mathrm{~Hz}, 1 \mathrm{H}), 4.27(\mathrm{dd}, J=8.9,1.5 \mathrm{~Hz}, 1 \mathrm{H}), 4.10(\mathrm{td}, J=8.5,6.5 \mathrm{~Hz}, 1 \mathrm{H}), 3.98(\mathrm{td}$, $J=8.5,6.3 \mathrm{~Hz}, 1 \mathrm{H}), 2.80(\mathrm{dd}, J=16.9,4.8 \mathrm{~Hz}, 1 \mathrm{H}), 2.63(\mathrm{dd}, J=16.9,5.9 \mathrm{~Hz}, 1 \mathrm{H}), 2.35$ (ddd, $J=13.0,8.4,6.4 \mathrm{~Hz}, 1 \mathrm{H}), 2.25$ (ddd, $J=13.0,8.2,6.5 \mathrm{~Hz}, 1 \mathrm{H})$ (Figure S1a). ${ }^{13} \mathrm{C}$ NMR $\left(126 \mathrm{MHz}, \mathrm{CDCl}_{3}\right) \delta=196.49(\mathrm{C}), 147.54(\mathrm{CH}), 128.82(\mathrm{CH}), 82.27(\mathrm{CH}), 75.80(\mathrm{C}), 66.26$ $\left(\mathrm{CH}_{2}\right), 40.24\left(\mathrm{CH}_{2}\right), 39.61\left(\mathrm{CH}_{2}\right)$. (Figure $\left.\mathrm{S1b}\right)$.

Cleroindicin C (4): ${ }^{1} \mathrm{H}$ NMR $\left(400 \mathrm{MHz}, \mathrm{CDCl}_{3}\right) \delta=4.03-3.96(\mathrm{~m}, 2 \mathrm{H}), 3.91(\mathrm{td}, J=8.9$, $7.4 \mathrm{~Hz}, 1 \mathrm{H}), 2.75(\mathrm{dd}, J=16.1,4.8 \mathrm{~Hz}, 1 \mathrm{H}), 2.59$ (ddd, $J=16.2,4.7,0.8 \mathrm{~Hz}, 1 \mathrm{H}), 2.50$ (ddd, $J=17.4,8.1,5.1 \mathrm{~Hz}, 1 \mathrm{H}), 2.30$ (dddd, $J=17.4,8.6,4.7,0.9 \mathrm{~Hz}, 1 \mathrm{H}), 2.21-2.06(\mathrm{~m}, 4 \mathrm{H})$ (Figure S1f). ${ }^{13} \mathrm{C}$ NMR (126 MHz, $\left.\mathrm{CDCl}_{3}\right) \delta=209.29(\mathrm{C}), 83.54(\mathrm{CH}), 65.95(\mathrm{CH}), 42.38$ $\left(\mathrm{CH}_{2}\right), 40.67\left(\mathrm{CH}_{2}\right), 35.00\left(\mathrm{CH}_{2}\right), 35.42\left(\mathrm{CH}_{2}\right)$ (Figure $\mathrm{S} 1 \mathrm{~g}$ ).

\subsection{Selective Extraction of Compound 3}

A total of $60 \mathrm{~g}$ of the fresh aerial parts of D. obscura collected in March 2021 were immersed in $\mathrm{EtOH}$ heated at $40{ }^{\circ} \mathrm{C}$ for $1 \mathrm{~h}$. After evaporation of the solvent, $450 \mathrm{mg}$ of extract was obtained. This extract was flash chromatographed (MTBE:EtOAc 2:1) to give $220 \mathrm{mg}$ of compound 3.

Compound 3. ${ }^{1} \mathrm{H}$ NMR $(400 \mathrm{MHz}, \mathrm{MeOD}) \mathrm{d}=7.01(\mathrm{~d}, J=10.2 \mathrm{~Hz}, 1 \mathrm{H}), 6.14(\mathrm{~d}$, $J=10.1 \mathrm{~Hz}, 1 \mathrm{H}), 3.66(\mathrm{t}, J=6.7 \mathrm{~Hz}, 2 \mathrm{H}), 1.97(\mathrm{t}, J=6.7 \mathrm{~Hz}, 2 \mathrm{H})$ (Figure S1d). ${ }^{13} \mathrm{C} \mathrm{NMR}$ $(126 \mathrm{MHz}, \mathrm{MeOD}) \delta=196.39(\mathrm{C}), 153.03(2 \times \mathrm{CH}), 126.48(2 \times \mathrm{CH}), 67.96(\mathrm{C}), 56.85\left(\mathrm{CH}_{2}\right)$, $42.36\left(\mathrm{CH}_{2}\right)$ (Figure S1e).

For acetylation of compound 3 with acetyl chloride, $0.07 \mathrm{ml}$ of collidine $(0.56 \mathrm{mmol})$ and $0.022 \mathrm{~mL}$ of acetyl chloride $(0.28 \mathrm{mmol})$ were added to a solution of compound 3 (40 mg, $0.26 \mathrm{mmol}$ ) in $3 \mathrm{~mL} \mathrm{DCM}$ cooled at $-78{ }^{\circ} \mathrm{C}$. The mixture was stirred for $2 \mathrm{~h}$ at this temperature. It was then poured into $2 \mathrm{~N} \mathrm{HCl}$ and extracted with MTBE $(20 \mathrm{~mL} \times 3)$. The combined organic layers were dried over anhydrous sodium sulfate and concentrated in vacuo. The resultant crude was purified by flash chromatography (H: MTBE 1:1) to give hallerone (5) (33 mg, 65\%). 
Hallerone (5). ${ }^{1} \mathrm{H}$ NMR (400 MHz, $\left.\mathrm{CDCl}_{3}\right) \delta=6.80(\mathrm{bd}, J=10.2 \mathrm{~Hz}, 1 \mathrm{H}), 6.12(\mathrm{bd}$, $J=10.2 \mathrm{~Hz}, 1 \mathrm{H}), 4.10(\mathrm{t}, J=6.5 \mathrm{~Hz}, 2 \mathrm{H}), 2.04(\mathrm{t}, J=6.6 \mathrm{~Hz}, 2 \mathrm{H}), 1.96(\mathrm{~s}, 3 \mathrm{H})$ (Figure S1i). ${ }^{13} \mathrm{C} \mathrm{NMR}\left(126 \mathrm{MHz} \mathrm{CDCl}_{3}\right) \delta=185.06(\mathrm{C}), 170.70(\mathrm{C}), 147.47(2 \times \mathrm{CH}), 128.99(2 \times \mathrm{CH})$, $75.20(\mathrm{C}), 59.11\left(\mathrm{CH}_{2}\right), 38.47\left(\mathrm{CH}_{2}\right), 21.22\left(\mathrm{CH}_{3}\right), 20.86\left(\mathrm{CH}_{3}\right)$ (Figure $\left.\mathrm{S} 1 \mathrm{j}\right)$.

Acetylation of compound 3 with $\mathrm{Ac}_{2} \mathrm{O}$. To a solution of compound $3(20 \mathrm{mg}, 0.13 \mathrm{mmol})$ in $1 \mathrm{~mL}$ pyridine cooled at $0{ }^{\circ} \mathrm{C}, 0.01 \mathrm{~mL}$ of $\mathrm{Ac}_{2} \mathrm{O}$ and a crystal of DMAP were added. The mixture was stirred for $30 \mathrm{~min}$ at this temperature and then $2 \mathrm{~h}$ at $\mathrm{rt}$. The reaction mixture was then poured into ice and extracted with MTBE $(20 \mathrm{~mL} \times 3)$. The combined organic layers were washed with $2 \mathrm{~N} \mathrm{HCl}(10 \mathrm{~mL} \times 3)$, saturated $\mathrm{NaHCO}_{3}(20 \mathrm{~mL} \times 3)$, and brine $(20 \mathrm{~mL} \times 3)$. Then, it was dried over anhydrous sodium sulfate and concentrated in vacuo. The resultant crude was purified by flash chromatography (H: MTBE 4:1) to give compound 6 (16 mg, 52\%).

Compound 6. ${ }^{1} \mathrm{H}$ NMR $(400 \mathrm{MHz}, \mathrm{CDCl} 3) \delta=6.88(\mathrm{~d}, J=10.2 \mathrm{~Hz}, 1 \mathrm{H}), 6.29(\mathrm{~d}$, $J=10.2 \mathrm{~Hz}, 1 \mathrm{H}), 4.18(\mathrm{t}, J=6.6 \mathrm{~Hz}, 2 \mathrm{H}), 2.17(\mathrm{t}, J=6.6 \mathrm{~Hz}, 2 \mathrm{H}), 2.07(\mathrm{~s}, 3 \mathrm{H}) ; 2.03(\mathrm{~s}, 3 \mathrm{H})$ (Figure S1k). ${ }^{13} \mathrm{C}$ NMR (126 MHz, $\left.\mathrm{CDCl}_{3}\right) \delta=184.81(\mathrm{C}), 170.60(\mathrm{C}), 169.19$ (C), 150.17 $(2 \times \mathrm{CH}), 128.27(2 \times \mathrm{CH}), 68.40(\mathrm{C}), 59.60\left(\mathrm{CH}_{2}\right), 38.72\left(\mathrm{CH}_{2}\right), 20.87\left(\mathrm{CH}_{3}\right)$ (Figure S11).

\subsection{Antifeedant Activity}

S. littoralis, M. persicae and R. padi colonies are maintained at ICA-CSIC, reared on artificial diet, bell pepper (Capsicum annuum) and barley (Hordeum vulgare) plants, respectively, and kept at $22 \pm 1{ }^{\circ} \mathrm{C}$ and $>70 \% \mathrm{RH}$, with a photoperiod of 16:8 h (L:D) in a custom-made walk-in growth chamber.

The bioassays were conducted as described [43]. The upper surface of C. annuum and $H$. vulgare leaf disks or fragments $\left(1.0 \mathrm{~cm}^{2}\right)$ were treated with $10 \mu \mathrm{L}$ of the test substance. The extracts and products were tested at an initial dose of 10 or $5 \mu \mathrm{g} / \mu \mathrm{L}\left(100\right.$ or $\left.50 \mu \mathrm{g} / \mathrm{cm}^{2}\right)$ respectively. A total of 5 to 7 Petri dishes or 20 ventilated plastic boxes $(2 \times 2 \mathrm{~cm})$ with 2 sixth-instar $S$. littoralis larvae ( $>24 \mathrm{~h}$ after molting) or 10 apterous aphid adults (24-48 h old) each were allowed to feed in a growth chamber (until 75\% larval consumption of control disks or $24 \mathrm{~h}$ for aphids, environmental conditions as above). Each experiment was repeated 2-3 times. Feeding inhibition or aphid settling was calculated by measuring the disk surface consumption (digitalized with https://imagej.nih.gov/ij/ (accessed on 3 March 2021) [47]) or by counting the number of aphids on each leaf fragment. Feeding/Settling inhibition $(\% \mathrm{FI}$ or $\% \mathrm{SI})$ was calculated as \% FI/SI $=[1-(\mathrm{T} / \mathrm{C}) \times 100]$, where $\mathrm{T}$ and $\mathrm{C}$ represent feeding/settling on treated and control leaf disks, respectively. The antifeedant effects (\% FI/SI) were analyzed for significance by the nonparametric Wilcoxon paired signed-rank test comparing the consumption/settling between the treatment and control leaf disks. Extracts and compounds with an SI $>70 \%$ were further tested in a dose-response experiment (1:2 serial dilutions to cover a range of activities between 100 and $<50 \%$ feeding inhibition with a minimum of 3 doses) to calculate their effective dose $\mathrm{EC}_{50}$ (dose to give a $50 \%$ settling reduction) from linear regression analysis (\% FI/SI on Log-dose, STATGRAPHICS Centurion XVI, version 16.1.02).

\subsection{Nematicidal Bioassay}

The M. javanica population was maintained on Lycopersicon esculentum plants (var. Marmande) in pot cultures at $25 \pm 1{ }^{\circ} \mathrm{C}, 70 \%$ relative humidity. Egg masses of $M$. javanica were hand-picked from infected tomato roots. Second-stage juveniles (J2) were obtained from hatched eggs by incubating egg masses in a water suspension at $25^{\circ} \mathrm{C}$ for $24 \mathrm{~h}$. Bioassays were performed in 96-well plates (BD Falcon, San Jose, CA, USA) as described by Andrés et al. [48]. Extracts and compounds were dissolved in water with 5\% of DMSOTween solution (0.5\% Tween 20 in DMSO), $5 \mu \mathrm{L}$ of this solution was added to $95 \mu \mathrm{L}$ of water containing 90-100 nematodes to obtain an initial concentration of $1 \mathrm{mg} / \mathrm{mL}$ per well. Treatments were replicated 4 times. As a control, 4 wells were filled with the water/DMSO/Tween 20 in the same volume as the test solutions. The plates were covered to prevent evaporation and were maintained in the dark at $25^{\circ} \mathrm{C}$. After $72 \mathrm{~h}$, the dead J2 
were counted under a binocular microscope. The nematicidal activity data were presented as percent dead J2s corrected according to Schneider-Orelli's formula [44]. Five serial concentrations of the active compound were tested to obtain an effective lethal dose (LD50) by Probit analysis (STATGRAPHICS Centurion XVI, version 16.1.02).

Supplementary Materials: The following are available online at https://www.mdpi.com/article/10 $.3390 /$ plants10050959/s1, Figure S1. copies of NMR spectra of compounds 1, 3, 4, 5, and $\mathbf{6}$.

Author Contributions: Conceptualization, A.F.B., A.G.-C., and J.F.Q.d.M.; investigation, A.G., Á.P., M.J.S.N., M.F.A. and A.G.-C.; writing-original draft preparation, J.F.Q.d.M.; writing-review and editing, A.F.B., A.G.-C., M.F.A. and J.F.Q.d.M.; funding acquisition, A.F.B., A.G.-C., M.F.A. and J.F.Q.d.M. All authors have read and agreed to the published version of the manuscript.

Funding: This work has been supported by grants MINISTERIO DE ECONOMÍA Y COMPETITIVIDAD, PID2019-106222RB-C32/SRA (State Research Agency, 10.13039/501100011033), PID2019106222RB-C31/SRA (State Research Agency, 10.13039/501100011033), ERASMUS + N²018-1-FR01KA202-047892 Biocontrol E Training (BET) and Unidad Asociada UGR-CSIC Bioplaguicidas: Biotecnología, síntesis y diversidad química.

Conflicts of Interest: The authors declare no conflict of interest.

\section{References}

1. Gerwick, B.C.; Sparks, T.C. Natural products for pest control: An analysis of their role, value and future. Pest Manag. Sci. 2014, 70, 1169-1185. [CrossRef] [PubMed]

2. Copping, L.G.; Duke, S.O. Natural products that have been used commercially as crop protection agents. Pest Manag. Sci. 2007, 63, 524-554. [CrossRef] [PubMed]

3. Glare, T.; Caradus, J.; Gelernter, W.; Jackson, T.; Keyhani, N.; Köhl, J.; Marrone, P.; Morin, L.; Stewart, A. Have biopesticides come of age? Trends Biotechnol. 2012, 30, 250-258. [CrossRef] [PubMed]

4. Cantrell, C.L.; Dayan, F.E.; Duke, S.O. Natural products as sources for new pesticides. J. Nat. Prod. 2012, 75, 1231-1242. [CrossRef] [PubMed]

5. Pavela, R. History, presence and perspective of using plant extracts as commercial botanical insecticides and farm products for protection against insects-A review. Plant Prot. Sci. 2016, 52, 229-241. [CrossRef]

6. Galisteo Pretel, A.; Pérez del Pulgar, H.; Olmeda, A.S.; Gonzalez-Coloma, A.; Barrero, A.F.; del Moral, Q.J.F. Novel Insect Antifeedant and Ixodicidal Nootkatone Derivatives. Biomolecules 2019, 9, 742. [CrossRef] [PubMed]

7. Barrero, A.F.; del Moral, Q.J.F.; Gonzalez-Coloma, A.; Andres, M.F.; Diaz, C.E. Derivados de germacrona para el control de plagas. Spain Patent ES2020070509, 10 August 2020.

8. Kreis, W. The foxgloves (Digitalis) revisited. Planta Med. 2017, 83, 962-976. [CrossRef]

9. El-Mallakh, R.S.; Brar, K.S.; Yeruva, R.R. Cardiac glycosides in human physiology and disease: Update for Entomologists. Insects 2019, 10, 102. [CrossRef]

10. Agrawal, A.A.; Petschenka, G.; Bingham, R.A.; Weber, M.G.; Rasmann, S. Toxic cardenolides: Chemical ecology and coevolution of specialized plant-herbivore interactions. New Phytol. 2012, 194, 28-45. [CrossRef]

11. Wang, X.-B.; Li, G.-H.; Zheng, L.-J.; Ji, K.-Y.; Lü, H.; Liu, F.-F.; Dang, L.-Z.; Mo, M.-H.; Zhang, K.-Q. Nematicidal cardenolides from Nerium indicum mill. Chem. Biodivers. 2009, 6, 431-436. [CrossRef]

12. Taskova, R.M.; Gotfredsen, C.H.; Jensen, S.R. Chemotaxonomic markers in Digitalideae (Plantaginaceae). Phytochemistry 2005, 66, 1440-1447. [CrossRef] [PubMed]

13. Nishino, C.; Kobayashi, K. 3A-hydroxy- or Acetoxy-3,3a,7,7a-tetrahydro-6(2H)-benzofuranone as Anticancer Agent. Japan Patent JP 01290627A, 22 November 1989.

14. Nishino, C.; Kobayashi, K. Tetrahydrobenzofurans as Antitumor Agents and Agrochemical Fungicides and Their Preparation. Japan Patent JP 01290666A, 22 November 1989.

15. Nagakura, A.; Sato, M.; Kikuchi, M.; Nakatsu, T. Anticancer Formulations Containing an Oxabicyclononenone Derivative. Japan Patent JP 02200631A, 8 August 1990.

16. Seo, J.Y.; Pyo, E.; Park, J.; Kim, J.-S.; Sung, S.H.; Oh, W.K. Nrf2-Mediated HO-1induction and antineuroinflammatory activities of halleridone. J. Med. Food 2017, 20, 1091-1099. [CrossRef]

17. Tuntiwachwuttikul, P.; Rayanil, K.; Taylor, W.C. Chemical constituents from the flowers of Nyctanthes arbor-tristis. ScienceAsia 2003, 29, 21-30. [CrossRef]

18. Phanthong, P.; Morales, N.P.; Chancharunee, S.; Mangmool, S.; Anantachoke, N.; Bunyapraphatsara, N. Biological activity of Dolichandrone serrulata flowers and their active components. Nat. Prod. Commun. 2015, 10, 1387-1390. [CrossRef] [PubMed]

19. Kutluay, V.M.; Makino, T.; Inoue, M.; Saracoglu, I. New knowledge about old drugs; a cardenolide type glycoside with cytotoxic effect and unusual secondary metabolites from Digitalis grandiflora Miller. Fitoterapia 2019, 134, 73-80. [CrossRef] 
20. Benítez, G.; González-Tejero, M.R.; Molero-Mesa, J. Knowledge of ethnoveterinary medicine in the Province of Granada, Andalusia, Spain. J. Ethnopharmacol. 2012, 139, 429-439. [CrossRef] [PubMed]

21. Roca-Pérez, L.; Boluda, R.; Gavidia, I.; Pérez-Bermúdez, P. Seasonal cardenolide production and Dop5 $\beta r$ gene expression in natural populations of Digitalis obscura. Phytochemistry 2004, 65, 1869-1878. [CrossRef] [PubMed]

22. Huber, K.; Meyer, K. Die Glykoside der Blätter von Digitalis obscura L. ssp. obscura. Helv. Chim. Acta 1966, 49, 259-272. [CrossRef]

23. Verma, S.K.; Das, A.K.; Cingoz, G.S.; Gurel, E. In vitro culture of Digitalis L. (Foxglove) and the production of cardenolides: An up-to-date review. Ind. Crops Prod. 2016, 94, 20-51. [CrossRef]

24. Albuquerque, B.R.; Prieto, M.A.; Barreiro, M.F.; Rodrigues, A.; Curran, T.P.; Barros, L.; Ferreira, I.C.F.R. Catechin-based extract optimization obtained from Arbutus unedo L. fruits using maceration/microwave/ultrasound extraction techniques. Ind. Crops Prod. 2017, 95, 404-415. [CrossRef]

25. Zhang, Q.-W.; Lin, L.-G.; Ye, W.-C. Techniques for extraction and isolation of natural products: A comprehensive review. Chin. Med. 2018, 13, 20. [CrossRef]

26. Munoz, L.; Rosell, G.; Quero, C.; Guerrero, A. Biosynthetic pathways of the pheromone of the Egyptian armyworm Spodoptera littoralis. Physiol. Entomol. 2008, 33, 275-290. [CrossRef]

27. Kim, J.H.; Jander, G. Myzus persicae (green peach aphid) feeding on Arabidopsis induces the formation of a deterrent indole glucosinolate. Plant J. 2007, 49, 1008-1019. [CrossRef] [PubMed]

28. Greenslade, A.F.C.; Ward, J.L.; Martin, J.L.; Corol, D.I.; Clark, S.J.; Smart, L.E.; Aradottir, G.I. Triticum monococcum lines with distinct metabolic phenotypes and phloem-based partial resistance to the bird cherry-oat aphid Rhopalosiphum padi. Ann. Appl. Biol. 2016, 168, 435-449. [CrossRef] [PubMed]

29. Castagnone-Sereno, P. Genetic variability and adaptive evolution in parthenogenetic root-knot nematodes. Heredity 2006, 96, 282-289. [CrossRef] [PubMed]

30. Tian, J.; Zhao, Q.-S.; Zhang, H.-J.; Lin, Z.-W.; Sun, H.-D. New cleroindicins from Clerodendrum indicum. J. Nat. Prod. 1997, 60, 766-769. [CrossRef]

31. Endo, K.; Hikino, H. Structures of rengyol, rengyoxide, and rengyolone, new cyclohexylethane derivatives from Forsythia suspensa fruits. Can. J. Chem. 1984, 62, 2011-2014. [CrossRef]

32. Messana, I.; Sperandei, M.; Multari, G.; Galeffi, C.; Bettolo, G.B.M. A cyclohexadienone and a cyclohexenone from Halleria lucida. Phytochemistry 1984, 23, 2617-2619. [CrossRef]

33. Breton, J.L.; Llera, L.D.; Navarro, E.; Trujillo, J. Photochemical synthesis of halleridone, hallerone, rengyol and derivatives. Tetrahedron 1987, 43, 4447-4451. [CrossRef]

34. Endo, K.; Seya, K.; Hikino, H. Biogenesis-like transformation of salidroside to rengyol and its related cyclohexyletanoids of Forsythia suspensa. Tetrahedron 1989, 45, 3673-3682. [CrossRef]

35. Carreño, M.C.; González-López, M.; Urbano, A. Oxidative de-aromatization of para-alkyl phenols into para-peroxyquinols and para-quinols mediated by oxone as a source of singlet oxygen. Angew. Chem. Int. Ed. 2006, 45, 2737-2741. [CrossRef]

36. Stermitz, F.R.; Krull, R.E. Iridoid glycosides of Cornus canadensis: A comparison with some other Cornus species. Biochem. Syst. Ecol. 1998, 26, 845-849. [CrossRef]

37. Bianco, A.; Scalzo, R.L.; Scarpati, M.L. Isolation of cornoside from Olea europaea and its transformation into halleridone. Phytochemistry 1993, 32, 455-457. [CrossRef]

38. Jensen, S.R. Chemical relationships of Polypremum procumbens, Tetrachondra hamiltonii and Peltanthera floribunda. Biochem. Syst. Ecol. 2000, 28, 45-51. [CrossRef]

39. Kim, D.-H.; Han, K.-M.; Bang, M.-H.; Lee, Y.-H.; Chung, I.-S.; Kim, D.-K.; Kim, S.-H.; Kwon, B.-M.; Park, M.-H.; Baek, N.-I. Cyclohexylethanoids from the flower of Campsis grandiflora. Bull. Korean Chem. Soc. 2007, 28, 1851-1853. [CrossRef]

40. Jensen, S.R.; Kjaer, A.; Nielsen, B.J. Quinol glucoside isolated from Cornus species. Acta Chem. Scand. 1973, 27, 367-369. [CrossRef]

41. Ishihara, K.; Kurihara, H.; Yamamoto, H. An extremely simple, convenient, and selective method for acetylating primary alcohols in the presence of secondary alcohols. J. Org. Chem. 1993, 58, 3791-3793. [CrossRef]

42. Navarro, E.; Alonso, S.J.; Boada, J.; Trujillo, J.; Ayuso, M.J.; Gutierrez Navarro, A. Quinolic derivatives: Biological activity. Fitoterapia 1992, 63, 251-254.

43. Navarro-Rocha, J.; Andrés, M.F.; Díaz, C.E.; Burillo, J.; González-Coloma, A. Composition and biocidal properties of essential oil from pre-domesticated Spanish Satureja montana. Ind. Crops Prod. 2020, 145, 111958. [CrossRef]

44. Püntener, W. Manual for Field Trials in Plant Protection; Ciba-Geigy Limited: Basel, Switzerland, 1981; 205p.

45. Lopes, M.B.P.; Mendonça, P.M.; Mallet, J.R.S.; Carvalho, M.G.; Queiroz, M.M.C. Bioactivity of the latex from Parahancornia amapa (Apocynaceae) on the development of Rhodnius nasutus (Hemiptera, Reduviidae, Triatominae) under laboratory conditions. Rev. Bras. Entomol. 2014, 58, 379-383. [CrossRef]

46. Fraga, B.M.; Díaz, C.E.; Amador, L.J.; Reina, M.; Santana, O.; González-Coloma, A. Bioactive compounds from transformed root cultures and aerial parts of Bethencourtia hermosae. Phytochemistry 2014, 108, 220-228. [CrossRef] [PubMed]

47. Rueden, C.T.; Schindelin, J.; Hiner, M.C.; DeZonia, B.E.; Walter, A.E.; Arena, E.T.; Eliceiri, K.W. ImageJ2: ImageJ for the next generation of scientific image data. BMC Bioinform. 2017, 18, 529. [CrossRef] [PubMed]

48. Andrés, M.F.; González-Coloma, A.; Sanz, J.; Burillo, J.; Sainz, P. Nematicidal activity of essential oils: A review. Phytochem. Rev. 2012, 11, 371-390. [CrossRef] 